\title{
UNNOTICED ETIOLOGY IN ORTHOPEDIC COMPLAINTS: CHRONIC MOUNTAIN SICKNESS
}

\section{ORTOPEDIK ŞIKAYETLERDE FARK EDILMEYEN ETIYOLOJi: KRONIK DAĞ HASTALIĞI}

\author{
Kayahan KARAYTUĞ ${ }^{1}$ iD, Mehmet EKINCi² ${ }^{10}$, Altuğ YÜCEKUL ${ }^{3}$ iD \\ ${ }^{1}$ Acibadem Maslak Hospital, Department of Orthopaedics and Traumatology, Istanbul, Turkey \\ ${ }^{2}$ Haseki Education and Training Hospital, Department of Orthopaedics and Traumatology, Istanbul, Turkey \\ ${ }^{3}$ Acibadem Mehmet Ali Aydınlar University, School of Medicine, Department of Orthopaedics and Traumatology, Istanbul, Turkey
}

ORCID IDs of the authors: K.K. 0000-0002-8138-8232; M.E. 0000-0001-5251-8280; A.Y. 0000-0002-1942-2444

Cite this article as: Karaytug K, Ekinci M, Yucekul A. Unnoticed etiology in orthopedic complaints: chronic mountain sickness. J Ist Faculty Med 2022;85(1):98-104. doi: 10.26650/IUITFD.929597

\section{ABSTRACT}

Objective: Chronic mountain sickness (CMS) is a clinical syndrome with symptoms of polycythemia that may interfere with other nonspecific diseases. The current study aimed to investigate the symptoms of patients living at high altitudes, who initially presented complaints that seemed to be common orthopedic problems, and to examine their relationship with chronic mountain sickness.

Materials and Methods: The prospectively collected data of 104 patients were retrospectively evaluated for serum hemoglobin $(\mathrm{Hb})$ and hematocrit $(\mathrm{Hct})$ levels, oxygen saturation $\left(\mathrm{sO}_{2}\right)$, Qinghai CMS questionnaire score, alcohol and tobacco use, "any history of acute mountain sickness, body mass index (BMI), blood pressure, heart rate, and duration of high-altitude living. Patients grouped according to the Qinghai score as healthy, mild, moderate or severe CMS. The groups were investigated in terms of parameters and demographic characteristics.

Results: Of the 104 patients, 33 (31.7\%) had a mild CMS score $\geq 6$ (28 patients, 6-10, 5 patients, 11-14 points); remaining patients had no CMS. The frequency of excessive erythrocytosis was $4.5 \%$ in men and $3.3 \%$ in women. There was a significant difference in $\mathrm{Hb}, \mathrm{Hct}$ and $\mathrm{sO}_{2}$ levels between the healthy and mild CMS groups $(p<0.001)$. CMS score had a positive correlation with $\mathrm{Hct}$ (rho 0.381, $\mathrm{p}<0.001$ ) and negative correlation between $\mathrm{sO}_{2}$ levels (rho -0.432, $p<0.001$ ).

Conclusions: CMS can be observed at lower altitudes than described in literature. In individuals living in high altitudes, some of the CMS symptoms may be confused with real orthopedic symptoms and orthopedists working in these areas should increase their awareness on this issue. In order to make an appropriate approach, other symptoms related to CMS should be questioned in patients living at high altitudes.

Keywords: Chronic mountain sickness, orthopedics symptoms, muscle joint pain, hemoglobin, oxygen saturation

\section{ÖZET}

Amaç: Kronik dağ hastalığı (KDH), diğer spesifik olmayan hastalıklarla da karışabilen polisitemi semptomları olan klinik bir sendromdur. Bu çalışmada, yüksek rakımlarda yaşayan, başlangıçta sık görülen ortopedik problemler gibi görünen şikayetlerle hastaneye başvuran hastaların semptomlarını araştırmayı ve kronik dağ hastalığı ile ilişkilerini incelemeyi amaçladık.

Gereç ve Yöntemler: Prospektif olarak toplanan 104 hastanın verileri retrospektif olarak incelendi. Hastaların serum hemoglobin $(\mathrm{Hb})$ ve hematokrit $(\mathrm{Hct})$ seviyeleri, oksijen satürasyonu $\left(\mathrm{sO}_{2}\right)$, Qinghai KDH anket skoru, alkol ve tütün kullanımı, herhangi bir akut dağ hastalığı öyküsü, vücut kitle indeksi (BMI), kan basıncı, kalp atış hızı ve yüksek rakımda yaşam süresi kaydedildi. Hastalar; Qinghai skoruna göre sağlıklı, hafif, orta veya şiddetli KDH olarak gruplandırıldı. Gruplar parametreler ve demografik özellikler açısından incelendi.

Bulgular: Yüz dört hastadan 33'ünün $(\% 31,7) \geq 6$ hafif $\mathrm{KDH}$ skoru vardı (28 hasta, 6-10, 5 hasta, 11-14 puan). Diğer hastalarda CMS saptanmadı. Aşırı eritrositoz sıklığı erkeklerde \%4,5, kadınlarda \%3,3 idi. Sağlıklı ve hafif CMS grupları arasında $\mathrm{Hb}$, Hct ve $\mathrm{sO}_{2}$ düzeyleri açısından anlamlı fark saptandı $(p<0,001)$. KDH skorunun Hct (rho 0,381, $\mathrm{p}<0,001$ ) ile pozitif, $\mathrm{sO}_{2}$ seviyeleri arasında negatif korelasyon ( $r$ o $-0,432, p<0,001$ ) saptandı.

Sonuç: Kronik dağ hastalığı, literatürde tarif edilenden daha düşük rakımlarda gözlemlenebilir. Yüksek yerlerde yaşayan bireylerde CMS semptomlarının bazılarının gerçek ortopedik semptomlarla karışabileceğinden ve bu bölgelerde çalışan ortopedistler bu konudaki farkındalıklarını arttırmalıdırlar. Bireysel semptomlar diğer hastalıkların bulguları ile kesişebilir ve özellikle benzer yaygın semptomları olan hastalıklarda KDH gözden kaçabilir. Uygun bir yaklaşımın yapılabilmesi için yüksek rakımlarda yaşayan hastalarda KDH ile ilgili diğer semptomların da sorgulanması gerekir.

Anahtar Kelimeler: Kronik dağ hastalığı, ortopedik semptomlar, kas-eklem ağrısı, hemoglobin, oksijen satürasyonu

Corresponding author/iletişim kurulacak yazar: kayhan_karaytug@hotmail.com

Submitted/Başvuru: 28.04.2021 • Revision Requested/Revizyon Talebi: 10.06.2021 •

Last Revision Received/Son Revizyon: 17.06.2021 • Accepted/Kabul: 23.06.2021 • Published Online/Online Yayın: 07.01.2022 


\section{INTRODUCTION}

Chronic mountain sickness (CMS) was first described by Carlos Monge in 1928 as a disease presenting diverse symptoms (1, 2). According to the International Consensus on Chronic and Sub-Acute High-Altitude Diseases, CMS is a clinical syndrome characterized by excessive erythrocytosis (EE) and severe hypoxemia observed in people living at high altitudes (>2500 m) (3). Chronic hypoxia results in pulmonary hypertension and polycythemia, accompanied by headache, fatigue, dizziness, dyspnea, sleep disturbances, and bone and muscle pain (4).

CMS is a weakening and debilitating disease that may occasionally interfere with other nonspecific diseases (5). As the population and life at high altitudes increase, the prevalence of related diseases will also increase. For these reasons, appropriate methods for diagnosis, treatment, and care are needed for people at risk of developing CMS (6). However, similar symptoms with other etiologies hamper its clinical recognition. A wide variety of neurological, cardiological, vestibular, or orthopedic symptoms can be misleading if incompletely evaluated or underestimated. Regarding the general complaints that can be met orthopedically, bone and joint pain, muscle aches, and burning in the hands and feet are the main musculoskeletal system problems observed in CMS (6-9).

Since the underlying etiological cause of CMS is different, a detailed analysis of its symptoms and application of the current CMS diagnosis algorithm will increase the success rate of diagnosis and treatment, especially in areas where CMS is a possibility. Various end-organ involvement of the symptoms and their relationship with the disease have been examined in previous publications (10-12). However, there are no studies in literature about the incidence of common orthopedic symptoms.

This study aims to investigate individuals who live at high altitudes with CMS risk and evaluate the role of CMS as an etiology in patients presenting general orthopedic complaints.

\section{MATERIALS AND METHODS}

This is an institutional review board-approved study, and informed consent was obtained from all patients included in the study. The patient group comprised individuals living in settlements located at an altitude of 2400-2600 meters in the Sarikamis district of Kars province in Turkey. The data of 217 patients, who visited the orthopedic department between November 2015 and January 2017, were retrospectively analyzed. Inclusion criteria were musculoskeletal pain, joint pain, or a burning sensation of the palms and feet. Symptoms were not associated with any disease findings based on the physical examination or laboratory and radiological tests. The exclu- sion criteria included age $<18$ years and $>65$ years old, chronic interstitial lung disease, chronic heart disease, pregnancy, menopause, history of lung surgery, history of nose surgery, and living in high-altitude areas for less than two months. CMS is a clinical syndrome characterized by excessive erythrocytosis (EE) and severe hypoxemia and is seen in people living at high altitudes (>2500 m). It is diagnosed using the Qinghai score in the absence of any condition that may cause hypoxemia and EE (5). The variables analyzed included serum hemoglobin $(\mathrm{Hb})$ and hematocrit (Hct) levels, the Qinghai CMS questionnaire score, oxygen saturation $\left(\mathrm{s}_{2}\right)$, alcohol and tobacco use, any history of acute mountain sickness, body mass index (BMI), blood pressure, heart rate, and the duration of living at high altitudes. CMS was diagnosed based on the Qinghai CMS score that includes $\mathrm{Hb}$ levels and seven signs and symptoms (breathlessness/palpitations, sleep disturbances, cyanosis, vein dilatation, paresthesia, headache, and tinnitus) (Table 1). EE was diagnosed using the parameters of the Qinghai score (both EE symptoms and $\mathrm{Hb}$ concentration level). The high cut-off value for serum $\mathrm{Hb}$ was $21 \mathrm{~g} / \mathrm{dL}$ in men and $19 \mathrm{~g} / \mathrm{dL}$ in women (3). If the $\mathrm{Hb}$ level was equal to or higher than the cut-off value, the $\mathrm{Hb}$ score was scored as 3 points; if the level was below the cut-off value, it was scored as 0 points. Each sign or symptom was scored between 0 and 3 points according to its severity. Arterial blood pressure was measured with a left-sided digital blood pressure monitor after the patient had rested for 30 minutes (13). Heart rate and oxygen saturation were measured with a digital pulse oximeter (Contec med CMS50D digital pulse oximeter, China) placed on the right middle finger (14). Patients who smoked more than 100 cigarettes in the past 30 days were categorized as smokers (15), and those who consumed $\geq 20 \mathrm{~g} /$ day of pure alcohol were categorized as drinkers (16). Patients were grouped according to the Qinghai score. Individuals with a Qinghai CMS score of $0-5$ points were considered healthy regarding CMS. In patients with $\mathrm{Hb}$ levels $\geq$ the cut-off value, a Qinghai score of 6-10 points was defined as mild CMS, 11-14 points as moderate CMS, and $\geq 15$ points as severe CMS (17). The groups were investigated regarding the parameters and demographic characteristics, and these parameters were correlated with disease severity (Figure 1).

\section{Statistical methods}

The distribution of variables was measured using the Kolmogorov-Smirnov test. The Mann-Whitney $U$ test was used to analyze independent quantitative data. The Chisquare test was used to analyze independent qualitative data, and Fischer's exact test was used when Chi-square test conditions were not met. The Spearman correlation analysis was used for correlation analysis. SPSS software (version 22.0, IBM Corp. Released 2013. Armonk, NY, USA) was used for the analyses. A p-value of $<0.05$ was considered significant. 
Table 1: The Qinghai Score for CMS

\section{Signs or symptoms Score}

Breathlessness

and/or

palpitations

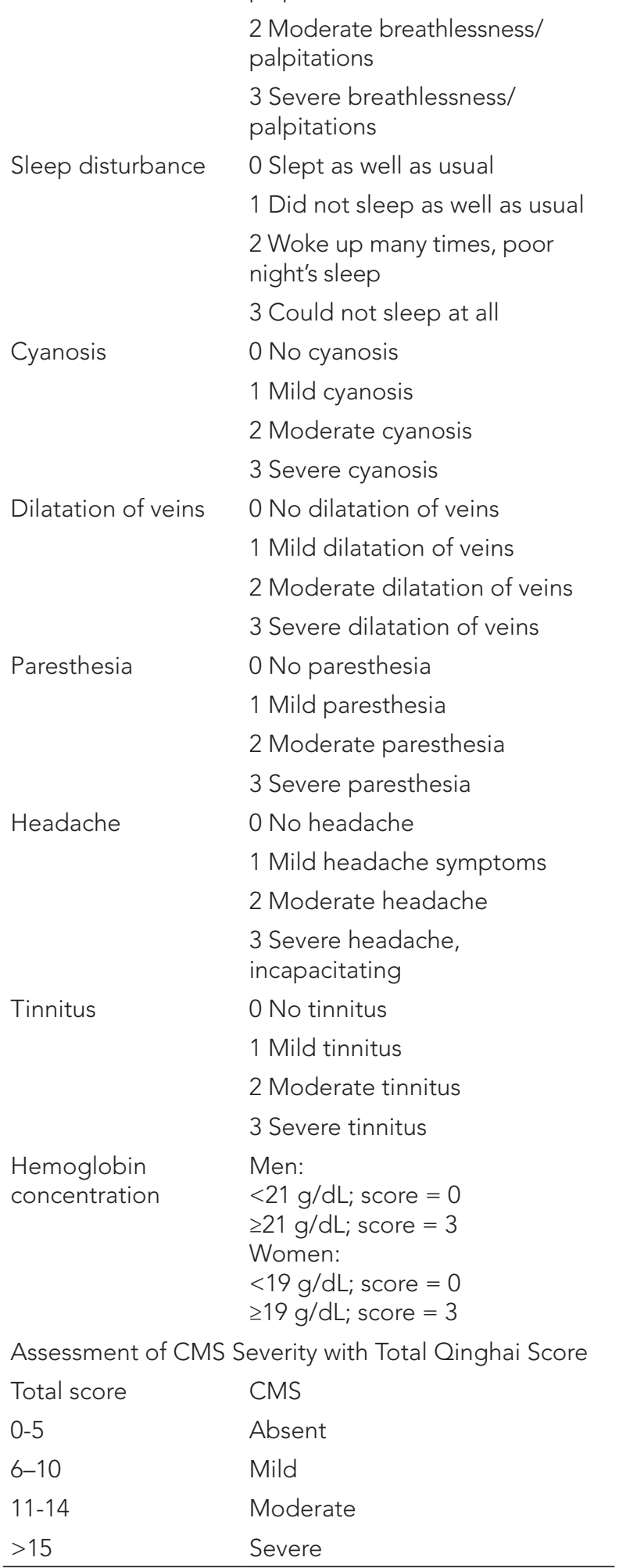

0 No breathlessness/palpitations

1 Mild breathlessness/

palpitations

2 Moderate breathlessness/

tions

3 Severe breathlessness/

0 Slept as well as usual

Did not sleep as well as usual

night's sleep

0 No cyanosis

1 Mild cyanosis

0 No dilatation of veins

Mild dilatation of veins

3 Severe dilatation of veins

0 No paresthesia

3 Severe paresthesia

headache

\section{en in Table 2.}

The healthy group comprised 71 individuals, 35 were females (49.3\%), and 36 were males (50.7\%), and their Qinghai CMS scores were between 0 and 5 points. The mean $\mathrm{Hb}$ and Hct were $16.4 \pm 12.6 \mathrm{mg} / \mathrm{dl}$ and $44.4 \pm 5.2 \%$ in the healthy group, respectively. The mean $\mathrm{sO}_{2}$ was $95.3 \pm 2.1$, and the median CMS score was $3 \pm 1.3$. The mean Hct was $47 \%$ in male patients, and $41.4 \%$ in female patients ( $p=0.873$ ).

The remaining 33 (31.7\%) patients in the cohort had CMS scores of $\geq 6$. Twenty-eight patients' scores were between 6 and 10 and were diagnosed as mild CMS, and five patients' scores were between 11 and 14 and were diagnosed as moderate CMS. Among them, 25 were females (75.8\%), and eight were males. The mean $\mathrm{Hb}$ and Hct were $16.9 \pm 2.2 \mathrm{mg} / \mathrm{dl}$ and $49.7 \pm 6.1 \%$ in the mild CMS group. The mean $\mathrm{sO}_{2}$ was $93.1 \pm 2$, and the median CMS score was $8.1 \pm 2$. In the mild CMS group, mean $\mathrm{Hb}$ and Hct were $16.7 \mathrm{mg} / \mathrm{dl}$ and $46.7 \%$ in female, $19.5 \mathrm{mg} / \mathrm{dl}$ and $53.7 \%$ in male patients, respectively $(p=0.218)$.

The $\mathrm{Hb}$ levels of only two male and two female patients were above the cut-off value for the diagnosis of EE. The 
Table 2: The demographics, laboratory results, evaluated cardiac and respiratory findings, and Qinghai scores of the cohort

\begin{tabular}{|c|c|c|c|c|c|}
\hline & $\mathrm{n}$ & $\%$ & Min-Max & Median & Mean \pm S.D \\
\hline Age & & & $18-65$ & 45 & $42.4 \pm 12.9$ \\
\hline \multicolumn{6}{|l|}{ Gender } \\
\hline Female & 60 & 57.7 & & & \\
\hline Male & 44 & 42.3 & & & \\
\hline BMI & & & $19.1-36.3$ & 24.8 & $25.4 \pm 3.9$ \\
\hline Alcohol & 1 & 1 & & & \\
\hline Tobacco & 20 & 19.2 & & & \\
\hline Time at high altitude ${ }^{a}$ & & & $3-65$ & 41 & $38.1 \pm 17.2$ \\
\hline Hemoglobin ${ }^{b}$ & & & $10.8-21.3$ & 15.2 & $16.5 \pm 10.4$ \\
\hline Hematocrit $^{c}$ & & & $31.1-60$ & 45 & $46.1 \pm 6$ \\
\hline Systolic blood pressured & & & $90-170$ & 130 & $126.4 \pm 18.4$ \\
\hline Diastolic blood pressure ${ }^{d}$ & & & $50-100$ & 70 & $74 \pm 12$ \\
\hline Oxygen saturation ${ }^{c}$ & & & $88-99$ & 95 & $94.6 \pm 2.4$ \\
\hline Heart Rate ${ }^{e}$ & & & $56-124$ & 72 & $76 \pm 12.3$ \\
\hline Qinghai CMS score & & & $1-14$ & 4 & $4.6 \pm 2.9$ \\
\hline
\end{tabular}

a: month, b: mg/dl, c: \%, d: $\mathrm{mmHg}$, e: beat per minute

BMI: Body Mass Index, SD: standard deviation

frequency of EE was $4.5 \%$ in male and $3.3 \%$ in female patients $(p=0.285)$.

The distribution of genders within groups was statistically different ( $\mathrm{p}=0.011)$. The mean $\mathrm{Hb}$, $\mathrm{Hct}$, and $\mathrm{sO}_{2}$ levels were significantly higher in the group with mild CMS than in the healthy group $(p<0.01)$. There was no statistically significant difference between the groups with CMS scores of $<5$ and $\geq 6$ regarding $\mathrm{BMI}$, alcohol and tobacco use, the duration of living at high altitudes, systolic and diastolic blood pressure, and heart rate. The comparison of the groups is provided in Table 3.

Table 3: Statistical analysis of parameters between healthy and mild Chronic Mountain Sickness (CMS) groups

\begin{tabular}{|c|c|c|c|c|c|c|c|}
\hline \multirow{2}{*}{ Parameters } & \multicolumn{3}{|c|}{ CMS score $\leq 5$} & \multicolumn{3}{|c|}{ CMS score $>6$} & \multirow{2}{*}{$p$ value } \\
\hline & $\mathrm{n}$ & $\%$ & Mean $\pm S D$ (min-max) & $\mathrm{n}$ & $\%$ & Mean $\pm S D$ (min-max) & \\
\hline Age & & & $41.1 \pm 14(18-65)$ & & & $45 \pm 9.7(20-61)$ & $0.148^{*}$ \\
\hline Gender & & & & & & & $0.011^{x}$ \\
\hline Female & 35 & 49.3 & & 25 & 75.8 & & \\
\hline Male & 36 & 50.7 & & 8 & 24.2 & & \\
\hline $\mathrm{BMI}$ & & & $25.3 \pm 3.9(19.1-36.3)$ & & & $25.7 \pm 4(19.5-34.1)$ & $0.701 *$ \\
\hline Time at high altitude ${ }^{a}$ & & & $36.9 \pm 18.4(18-65)$ & & & $40.9 \pm 14.3(1-61)$ & $0.287^{*}$ \\
\hline Hemoglobin ${ }^{b}$ & & & $16.4 \pm 12.6(11-21)$ & & & $16.9 \pm 2.2(13-21)$ & $0.000^{*}$ \\
\hline Hematocritc & & & $44.4 \pm 5.2(31-60)$ & & & $49.7 \pm 6.1(38-60)$ & $0.000^{\star}$ \\
\hline Systolic blood pressure ${ }^{d}$ & & & $125 \pm 20(90-170)$ & & & $129.2 \pm 13(100-150)$ & $0.310^{*}$ \\
\hline Diastolic blood pressure & & & $73.9 \pm 12.5(38-100)$ & & & $74.4 \pm 11.1(60-100)$ & $0.975^{\star}$ \\
\hline Oxygen saturation ${ }^{c}$ & & & $95.3 \pm 2.1(88-99)$ & & & $93.1 \pm 2.3(88-97)$ & $0.000^{*}$ \\
\hline Heart Rate ${ }^{e}$ & & & $76.6 \pm 12.4(60-124)$ & & & $74.8 \pm 12.2(56-107)$ & $0.545^{\star}$ \\
\hline Qinghai CMS score & & & $3 \pm 1.3$ & & & $8.1 \pm 2$ & \\
\hline
\end{tabular}

r: Chi-square test, *: Mann-Whitney U test, a: month, b: $\mathrm{mg} / \mathrm{dl}, \mathrm{c}: \%, \mathrm{~d}: \mathrm{mmHg}$, e: beat per minute BMI: Body Mass Index, SD: standard deviation 
The correlation was found to be weakly positive between Hct and CMS scores (rho 0.381, p<0.001) and weakly negative between $\mathrm{sO}_{2}$ values and CMS scores (rho -0.432 , $\mathrm{p}<0.001$ ). There was no significant correlation between the CMS score and the mean $\mathrm{Hb}$ level (rho -0.012, $\mathrm{p}=0.907)$.

\section{DISCUSSION}

The current study is the first to evaluate CMS in patients with common orthopedic complaints who live in a high-altitude province. Based on Qinghai CMS scores and laboratory findings, in residents living at around 2500 m altitude, 33 of 104 patients (32\%) with common orthopedic symptoms had mild CMS. In addition to the disease being prevalent in women, a weak correlation was found between hematocrit, oxygen saturation, and disease severity.

Symptoms observed in CMS are headache, difficulty breathing, sleep disturbances, fatigue, palpitations, localized cyanosis, especially of the hands and lips, a burning sensation in the palms and feet, muscle and joint pain, loss of appetite, dizziness, attention deficit, and mental fatigue (18). Similar to the other symptoms mentioned, orthopedic symptoms are common complaints. Muscle and joint pain and burning in the hands and feet are common symptoms in orthopedic clinics and can be associated with different pathologies. Extremity problems and joint symptoms related to polycythemia and burning feet with erythromelalgia have been reported previously in different diseases $(19,20)$. In polycythemia, joint problems are generally caused by hyperuricemia and the development of synovitis in the joints with crystal deposition over time, while drug-induced peripheral neuropathy or hypoxia due to hyperviscosity is the reason for hand-foot burning (19-21). Orthopedic symptoms can be seen in CMS based on similar pathophysiology. However, when the disease is not known exactly, they can be unnoted. Its clinical findings and associated symptoms can be used to distinguish CMS from other etiologies. Most prominently, some or all of these symptoms should be present in patients at high altitudes. The clinical picture becomes less severe at lower altitudes and sometimes disappears, only to reappear at higher altitudes (6). In humans with better adaptation to chronic hypoxia, lower hemoglobin $\mathrm{Hb}$ values lead to a lower incidence of erythrocytosis and CMS. In contrast, EE and elevated $\mathrm{Hb}$ levels lead to pronounced clinical symptoms (17).

The definition and diagnostic criteria of CMS are debatable. One essential point that is not agreed upon in $\mathrm{CMS}$ is the $\mathrm{Hb}$ threshold value. The increase in $\mathrm{Hb}$ level is an adaptive mechanism following prolonged exposure to chronic hypoxia and is dependent on the severity of hypoxia and the altitude. For this reason, different $\mathrm{Hb}$ thresholds have been used according to the different al- titude levels in studies related to CMS. The cut-off value of $\mathrm{Hb}$ was determined to be $21 \mathrm{~g} / \mathrm{dL}$ for men and $19 \mathrm{~g} / \mathrm{dL}$ for women by the World Congress on Mountain Medicine and High-Altitude Physiology (3). In past publications, the cut-off value of $\mathrm{Hb}$ was reported to be 2,3 , or 4 standard deviations above the mean level in the affected area (22). Jiang and colleagues reported that an $\mathrm{Hb}$ cut-off value of $20 \mathrm{~g} / \mathrm{dL}$, rather than $21 \mathrm{~g} / \mathrm{dL}$, was more appropriate for all altitudes. Because of these controversial points, some researchers suggest that the use of laboratory parameters, such as $\mathrm{sO}_{2}$, carbon dioxide retention, and the $\mathrm{Hb}$ level, may be more appropriate for CMS scoring (23). We found the mean $\mathrm{Hb}$ value of $17.4 \mathrm{~g} / \mathrm{dL}$ in the group with CMS and a significant correlation between mean Hct levels and CMS scores. In general, the low $\mathrm{Hb}$ and Hct compared with similar studies may be due to ethnic differences or lower altitudes.

The prevalence of CMS varies mainly according to the altitude with other affecting parameters like age, sex, altitude, the duration spent at high altitudes, smoking and alcohol use, chronic diseases, population, and ethnic characteristics (22). The most populated area at high-altitude is the Tibetan plateau. In a study, the prevalence of CMS in the Tibetan plateau was $17.8 \%$, which is higher than that of previous studies (18). Spielvogel et al. found a prevalence of 5.2\% in the La Paz area (3600 m) (24). De Ferrari and colleagues reported a prevalence of $6 \%$ in the Puno area (3800 m) (25). Monge and colleagues observed a prevalence of $15.4 \%$ in men aged $30-39$ years in Cerro de Pasco $(4380 \mathrm{~m})$ (26). Although the prevalence of CMS varies in the range of $5 \%$ to $10 \%$ above $2500 \mathrm{~m}$ (5), the actual prevalence below $3000 \mathrm{~m}$ is unknown. In a study with a limited number of participants, the prevalence below $3000 \mathrm{~m}$ was $0 \%$. However, there was a serious methodological limitation because $\mathrm{Hb}$ and blood values were not examined in the study (27). In addition, there is a physiological change at altitudes above $2500 \mathrm{~m}$. At an altitude of 2500 to 3000 meters, the prevalence of acute mountain disease is from $8 \%$ to $25 \%$ (28-30). In our study, patients who applied to the hospital at an altitude of 2500 meters were included. The high rate of mild CMS (32\%) found in our study was beyond the prevalence of the disease at that altitude. It showed the disease incidence in patients presenting with similar orthopedic complaints. The true prevalence can be determined by screening the asymptomatic population and symptomatic patients.

Chronic hypoxia and the resulting polycythemia play essential roles in the pathophysiology of CMS (31). Thus, CMS can be divided into two groups: primary CMS and secondary CMS. Primary CMS is caused by aggravated hypoxemia and increased erythrocyte concentration without an underlying cause. Secondary CMS occurs due to hypoxia caused by lung or heart disease (10). Therefore, in our study, to rule out secondary CMS, patients 
with known heart or lung problems or associated illnesses were not included. Living at high altitudes for a long time and older age are also other important risk factors for the disease. Residing at high altitudes for longer than 60 months increases the CMS risk (5). In our study, CMS and healthy groups had a mean duration of 45 months and 37 months at high altitudes, respectively. The duration of the two groups reduced the risk-creating effect of time. Also, with the exclusion of patients over 65 years of age, attempts were made to minimize the effects of age.

CMS is a pathology seen at high altitudes and contains nonspecific symptoms. So, patients may refer to different outpatient clinics, and the diagnosis may be overlooked. Our study aims to draw attention to this rare pathology. Following the diagnosis, we referred our patients diagnosed with CMS to the department of internal medicine for their treatment.

Although we attempted to exclude secondary CMS in this study, it is difficult to achieve this completely. On the other hand, since the symptoms are similar whether CMS is primary or secondary, the complaints of individuals with chronic lung problems and heavy smokers living at high altitudes, which always seem orthopedic, may be related to CMS.

There are some limitations of our study. Since the seriousness of orthopedic complaints is not questioned within the Qinghai scoring system, the severity and duration of orthopedic symptoms were unknown. However, patients who were not associated with any disease findings based on their physical examination, laboratory and radiological tests were included in the study, and attempts were made to show the relationship of the disease to the patients. In diagnosing the disease, the subjective evaluation findings included in the scoring system create another limitation, despite the accompanying measurable evaluations. Since there was no aim to find the incidence of the disease, a scoring system was used by adding measurable values, such as oxygen saturation and blood pressure, to guide the etiology. However, further studies with larger patient cohorts and more detailed analyses are needed to investigate patient groups with similar complaints.

\section{CONCLUSION}

Many parameters play active roles in the development of CMS. When the symptoms are assessed individually, they may intersect with those of other diseases. Thus, the diagnosis of CMS may be missed. This study showed that CMS could occur at lower altitudes than those described in literature. Therefore, in the orthopedic clinic, this disease should be kept in mind, and patients should be questioned regarding the possibility of CMS to resolve the complaints of patients, which can be related to different etiopathogenesis.
Informed Consent: Written consent was obtained from the participants.

Ethics Committee Approval: This study was approved by the Clinical Research Ethical Committee of the Acıbadem University. (Date: 21.04.2021, No: 08)

Peer Review: Externally peer-reviewed.

Author Contributions: Conception/Design of Study- K.K.; Data Acquisition- K.K.; Data Analysis/Interpretation- K.K., M.E., A.Y.; Drafting Manuscript- K.K.; Critical Revision of Manuscript- M.E., A.Y.; Approval and Accountability- K.K., M.E., A.Y.

Conflict of Interest: Authors declared no conflict of interest

Financial Disclosure: Authors declared no financial support.

\section{REFERENCES}

1. Monge C. Life In The andes and chronic mountain sickness. Science 1942;95(2456):79-84. [CrossRef]

2. Monge CC, Whittembury J. Chronic mountain sickness Johns Hopkins Med J 1976;139 SUPPL:87-9.

3. Rimoldi SF, Rexhaj E, Pratali L, Bailey DM, Hutter D, Faita F, et al. Systemic vascular dysfunction in patients with chronic mountain sickness. Chest 2012;141(1):139-46. [CrossRef]

4. Wright AD, Beazley MF, Bradwell AR, Chesner IM, Clayton RN, Forster PJ, et al.; Birmingham Medical Research Expeditionary Society. Medroxyprogesterone at high altitude. The effects on blood gases, cerebral regional oxygenation, and acute mountain sickness. Wilderness Environ Med 2004;15(1):25-31. [CrossRef]

5. León-Velarde F, Maggiorini M, Reeves JT, Aldashev A, Asmus I, Bernardi L, et al. Consensus statement on chronic and subacute high altitude diseases. High Alt Med Biol 2005;6(2):147-57. [CrossRef]

6. Villafuerte FC, Corante N. Chronic mountain sickness: Clinical aspects, etiology, management, and treatment. High Alt Med Biol 2016;17(2):61-9. [CrossRef]

7. Groepenhoff $H$, Overbeek MJ, Mulè $M$, van der Plas $M$, Argiento P, Villafuerte FC, et al. Exercise pathophysiology in patients with chronic mountain sickness exercise in chronic mountain sickness. Chest 2012;142(4):877-84. [CrossRef]

8. West JB. Hypoxia, polycythemia, and chronic mountain sickness. Chest 1988;94(1):22-3. [CrossRef]

9. Thomas PK, King RH, Feng SF, Muddle JR, Workman JM, Gamboa J, et al. Neurological manifestations in chronic mountain sickness: the burning feet-burning hands syndrome. J Neurol Neurosurg Psychiatry 2000;69(4):447-52. [CrossRef]

10. Penaloza D, Arias-Stella J. The heart and pulmonary circulation at high altitudes: healthy highlanders and chronic mountain sickness. Circulation 2007;115(9):1132-46. [CrossRef]

11. Lozano R, Monge $C$. Renal function in high-altitude natives and in natives with chronic mountain sickness. J Appl Physiol 1965;20(5):1026-7. [CrossRef]

12. Gonzales GF, Gasco M, Tapia V, Gonzales-Castañeda C. High serum testosterone levels are associated with excessive erythrocytosis of chronic mountain sickness in men. Am J Physiol Endocrinol Metab 2009;296(6):E1319-25. [CrossRef] 
13. Mahe G, Comets E, Nouni A, Paillard F, Dourmap C Le Faucheur $A$, et al. A minimal resting time of $25 \mathrm{~min}$ is needed before measuring stabilized blood pressure in subjects addressed for vascular investigations. Sci Rep 2017;7(1):12893. [CrossRef]

14. Basaranoglu G, Bakan M, Umutoglu T, Zengin SU, Idin K, Salihoglu Z. Comparison of SpO2 values from different fingers of the hands. Springerplus 2015;4:561. [CrossRef]

15. Wang M, Wang JW, Cao SS, Wang HQ, Hu RY. Cigarette smoking and electronic cigarettes use: A meta-analysis. Int J Environ Res Public Health 2016;13(1):120. [CrossRef]

16. Ryu M, Kimm H, Jo J, Lee SJ, Jee SH. Association between alcohol intake and abdominal obesity among the Korean population. Epidemiol Health 2010;32:e2010007. [CrossRef]

17. Gonzales GF, Rubio J, Gasco M. Chronic mountain sickness score was related with health status score but not with hemoglobin levels at high altitudes. Respir Physiol Neurobiol 2013;188(2):152-60. [CrossRef]

18. Jiang C, Chen J, Liu F, Luo Y, Xu G, Shen HY, et al. Chronic mountain sickness in Chinese Han males who migrated to the Qinghai-Tibetan plateau: application and evaluation of diagnostic criteria for chronic mountain sickness. BMC Public Health 2014;14:701. [CrossRef]

19. Denman AM, Szur L, Ansell Bm. Joint complaints in polycythaemia vera. Ann Rheum Dis 1964;23(2):139-44. [CrossRef]

20. Wollina U. Burning feet in polycythemia vera - peripheral sensorimotor axonal neuropathy with erythromelalgia. Int J Gen Med 2015;8:69-71. [CrossRef]

21. Reuss-Borst MA, Pape CA, Tausche AK. Hidden goutUltrasound findings in patients with musculo-skeletal problems and hyperuricemia. Springerplus 2014;3:592. [CrossRef]

22. Wu TY, Li W, Li Y, Ge RL, Cheng Q, Wang S, et al. Progress in mountain medicine and high altitude physiology. In: $\mathrm{H}$. Ohno, T. Kobayashi, and S. Ma- suyama, M. Nakashima, editors. Epidemiology of chronic mountain sickness: Ten years' study in Quinghai-Tibet. In: Progress in Mountain Medicine and High Altitude Physiology. Press Committee of the Third World Congress, Matsumoto; pp. 120-125.
23. Gonzales GF, Tapia V, Gasco M, Gonzales-Castañeda C. Serum testosterone levels and score of chronic mountain sickness in Peruvian men natives at $4340 \mathrm{~m}$. Andrologia 2011;43(3):189-95. [CrossRef]

24. Spielvogel H, Vargas E, Paz Zamora M, Haas J, Beard JL, Tufts $G$, et al. Poliglobulia y ejercicio muscular. Gaceta del Thorex 1981;8(4):6-12.

25. De Ferrari A, Miranda JJ, Gilman RH, Dávila-Román VG, León-Velarde F, Rivera-Ch M, et al. Prevalence, clinical profile, iron status, and subject-specific traits for excessive erythrocytosis in andean adults living permanently at 3,825 meters above sea level. Chest 2014;146(5):1327-36. [CrossRef]

26. Monge C, León-Velarde F, Arregui A. Increasing prevalence of excessive erythrocytosis with age among healthy highaltitude miners. N Engl J Med 1989;321(18):1271. [CrossRef]

27. Sahota IS, Panwar NS. Prevalence of Chronic Mountain Sickness in high altitude districts of Himachal Pradesh. Indian J Occup Environ Med 2013;17(3):94-100. [CrossRef]

28. Montgomery AB, Mills J, Luce JM. Incidence of acute mountain sickness at intermediate altitude. JAMA 1989;261(5):732-4. [CrossRef]

29. Maggiorini M, Bühler B, Walter M, Oelz O. Prevalence of acute mountain sickness in the Swiss Alps. BMJ 1990;301(6756):853-5. [CrossRef]

30. Honigman B, Theis MK, Koziol-McLain J, Roach R, Yip R, Houston $C$, et al. Acute mountain sickness in a general tourist population at moderate altitudes. Ann Intern Med 1993;118(8):587-92. [CrossRef]

31. León-Velarde F, Richalet JP. Respiratory control in residents at high altitude: physiology and pathophysiology. High Alt Med Biol 2006;7(2):125-37. [CrossRef] 